\title{
STRES DAN TINGKAT KECEMASAN SAAT DITETAPKAN PERLU HEMODIALISIS BERHUBUNGAN DENGAN KARAKTERISTIK PASIEN
}

\author{
Rahma Fadillah Sopha ${ }^{1 *}$, Ice Yulia Wardani ${ }^{1}$ \\ 1. Fakultas Ilmu Keperawatan, Universitas Indonesia, Kampus FIK UI, Depok, 16424, Indonesia \\ *E-mail: sova.fadillah@gmail.com
}

\begin{abstract}
Abstrak
Stres dan kecemasan merupakan kondisi psikologis yang umumnya dirasakan pasien penyakit ginjal kronis. Penelitian ini bertujuan untuk mengetahui hubungan karakteristik pasien penyakit ginjal kronis dengan tingkat stres dan kecemasan saat ditetapkan mendapatkan terapi hemodialisis. Penelitian ini menggunakan metode survei analitik cross sectional dengan melibatkan 32 pasien yang baru ditetapkan mendapatkan terapi hemodialisis. Untuk mengetahui tingkat stres dan kecemasan digunakan Depression Anxiety and Stress Scale. Dengan menggunakan uji kai kuadrat, didapatkan kesimpulan terdapat hubungan antara tingkat stres dengan usia dan tingkat pendidikan, sedangkan tingkat kecemasan berhubungan dengan usia, jenis kelamin, status perkawinan, dan status bekerja ( $p$ value $\leq 0,05)$. Hasil ini menunjukkan bahwa stres dan tingkat kecemasan saat ditetapkan mendapatkan terapi hemodialisis berhubungan dengan karakteristik pasien penyakit ginjal kronis. Hal ini memunculkan suatu kebutuhan akan adanya asuhan keperawatan untuk mengurangi stres dan kecemasan yang disesuaikan dengan karakteristik pasien.
\end{abstract}

Kata kunci: hemodialisis, kecemasan, stres

\begin{abstract}
Relationship between the Characteristics of Chronic Kidney Disease Patient and the Level of Stress and Anxiety when was Diagnosed to Acquire Hemodialysis therapy in RSUP Fatmawati. Stress and anxiety are psychological conditions that generally occurred on chronic kidney disease patients. This study aimed to determine the relationship between the characteristics of chronic kidney disease patients and the levels of stress and anxiety when was diagnosed to acquire hemodialysis therapy. This study used cross sectional survey method which evaluated 32 patients who were newly assigned to get hemodialysis therapy. To determine the level of stress and anxiety, it was used Depression Anxiety and Stress Scale. Using the chi-square test, it was concluded there was a relationship between the level of stress with age and educational level and the level of anxiety with age, gender, marital status, and work status ( $p$ value $\leq 0.05$ ). These results indicated that the differences in levels of stress and anxiety when was diagnosed to acquire hemodialysis therapy was associated with the characteristics of chronic kidney disease patients. So it would cause a necessity of nursing care plan to reduce stress and anxiety based on patients' characteristics.
\end{abstract}

Keywords: anxiety, hemodialysis, stress

\section{Pendahuluan}

Penyakit Ginjal Kronis (PGK) menduduki peringkat ke-12 sebagai penyakit dengan kematian tertinggi di dunia. Pusat Data \& Informasi Perhimpunan Rumah Sakit Seluruh Indonesia mengatakan jumlah pasien gagal ginjal teminal di Indonesia sekitar 50 orang per satu juta penduduk. Pasien PGK yang mencapai tahap gagal ginjal terminal membutuhkan terapi agar fungsi ginjal dapat diper- tahankan. Salah satu bentuk terapi tersebut adalah hemodialisis (Baradero, Dayrit, \& Siswadi, 2005).

Penyakit gagal ginjal kronis dan hemodialisis (HD) sebagai suatu peristiwa yang menimbulkan pengalaman emosi negatif yang dinamakan stressor. Stressor yang ditanggapi dengan baik membuat individu tumbuh semakin matang. Sebaliknya, stressor yang tidak ditanggapi dengan baik memicu mun- 
culnya respons psikologis berupa cemas, depresi, marah, takut, merasa bersalah, bahkan kematian (DeLaune \& Ladner, 2011; Caninsti, 2007; Farida, 2010; Kimmel, 2001). Respons ini melibatkan dua mekanisme, yaitu biologis dan psikologis yang bergantung pada usia, jenis kelamin, pendidikan, status perkawinan, lingkungan tempat tinggal, dan pekerjaan (Kimmel, 2001).

Penelitian tentang stres dan kecemasan bagi pasien PGK umumnya dilakukan saat pasien telah menjalani terapi $\mathrm{HD}$, bukan saat pasien pertama kali ditetapkan untuk mendapat terapi. Penting bagi perawat untuk memperhatikan perubahan psikologis yang terjadi saat pasien mendengar ketetapan mendapatkan terapi HD karena hal itu dapat memengaruhi langkah yang pasien ambil dalam mengobati penyakitnya. Penting pula bagi perawat untuk memperhatikan karakteristik pasien karena hal ini berpengaruh terhadap psikologis pasien. Pendeteksian dini terhadap stres dan kecemasan diharapkan dapat mempercepat pemberian tindakan (Andrade \& Sesso, 2012). Hal ini mendasari penelitian guna mengetahui hubungan karakteristik pasien PGK dengan tingkat stres dan kecemasan saat ditetapkan mendapatkan terapi HD.

\section{Metode}

Penelitian ini menggunakan metode survei analitik cross sectional dengan jumlah sampel 32 responden. Pasien yang termasuk kriteria inklusi yaitu pasien PGK baru, memahami bahasa Indonesia, dan bersedia mengisi kuesioner, pasien PGK dengan riwayat penyakit jiwa, pasien dengan gangguan pendengaran, berbicara, dan kognitif yang dapat mengganggu pemahaman pasien terhadap kuesioner, tidak dapat berkomunikasi atau pasien dalam keadaan koma. Teknik sampling yang digunakan yaitu jenis sampling nonprobabilitas dengan metode convenience sampling. Pengumpulan data dilakukan dengan kuesioner yang terdiri dari dua bagian. Bagian pertama berupa data karakteristik responden meliputi usia, jenis kelamin, tingkat pendidikan, status perkawinan, status bekerja, status ekonomi, cara pembayaran terapi HD, lama mengidap PGK, serta etiologi PGK. Bagian kedua yaitu kuesioner Depression Anxiety and Stress Scale (DASS) yang telah diterjemahkan ke dalam Bahasa Indonesia. Uji instrumen didapatkan nilai reliabilitas kecemasan sebesar 0,691 dan nilai reliabilitas stres sebesar 0,886 .

Penelitian ini telah lolos kaji etik dari Tim Kaji Etik. Pengambilan data bertempat di Unit Hemodialisa pada tanggal 2-30 Mei 2014. Pengambilan data dilakukan saat responden menjalani terapi HD dengan cara membacakan kuesioner. Data hasil penelitian diolah menggunakan analisis bivariat yang bertujuan mengetahui hubungan antara karakteristik pasien PGK dengan tingkat stres dan kecemasan saat ditetapkan mendapatkan terapi HD. Jenis data yang didapatkan pada penelitian ini dinyatakan dalam bentuk katagorik dan uji untuk mengetahui hubungan antara dua variabel katagorik adalah uji kai kuadrat.

\section{Hasil}

Hasil uji statistik antara karakteristik pasien PGK dengan tingkat stres dan kecemasan saat ditetapkan mendapatkan terapi HD terlihat pada tabel 1 dan 2 .

Berdasarkan tabel 1 diketahui bahwa sebagian besar responden berada dalam rentang usia dewasa, berjenis kelamin perempuan, tingkat pendidikan menengah, status perkawinan cerai/janda/duda, tidak bekerja, status ekonomi rendah, dan lama mengidap $\mathrm{PJK} \leq 1$ tahun. Hasil uji statistik menunjukkan ada hubungan antara usia dengan tingkat stres. Selain itu terdapat hubungan antara tingkat pendidikan dengan tingkat stres. Berdasarkan tabel 2 diketahui bahwa usia berhubungan dengan tingkat ansietas. 
Tabel 1. Hubungan Karakteristik Pasien PGK dengan Tingkat Stres saat Ditetapkan Mendapatkan Terapi Hemodialisis di Jakarta

\begin{tabular}{|c|c|c|c|c|c|c|c|c|c|}
\hline \multirow{3}{*}{ Karakteristik } & \multicolumn{6}{|c|}{ Tingkat Stres } & \multirow{2}{*}{\multicolumn{2}{|c|}{ Total }} & \multirow{3}{*}{$P$ value } \\
\hline & \multicolumn{2}{|c|}{ Normal } & \multicolumn{2}{|c|}{ Ringan-Sedang } & \multicolumn{2}{|c|}{ Berat-Sangat Berat } & & & \\
\hline & $\bar{n}$ & $\%$ & $\mathbf{n}$ & $\%$ & $\bar{n}$ & $\%$ & $\mathbf{n}$ & $\%$ & \\
\hline \multicolumn{10}{|l|}{ Usia } \\
\hline Dewasa & 3 & 13,6 & 10 & 45,5 & 9 & 40,9 & 22 & 100 & \multirow[t]{2}{*}{$0,018 *$} \\
\hline Lansia & 6 & 60,0 & 1 & 10,0 & 3 & 30,0 & 10 & 100 & \\
\hline \multicolumn{10}{|l|}{ Jenis Kelamin } \\
\hline Laki-laki & 2 & 16,7 & 3 & 25,0 & 7 & 58,3 & 12 & 100 & \multirow[t]{2}{*}{0,165} \\
\hline Perempuan & 7 & 35,0 & 8 & 40,0 & 5 & 25,0 & 20 & 100 & \\
\hline \multicolumn{10}{|l|}{ Tingkat Pendidikan } \\
\hline Tinggi & 4 & 57,1 & 2 & 28,6 & 1 & 14,3 & 7 & 100 & \multirow{3}{*}{$0,028 *$} \\
\hline Menengah & 2 & 11,8 & 9 & 52,9 & 6 & 35,3 & 17 & 100 & \\
\hline Rendah & 3 & 37,5 & 0 & 0 & 5 & 62,5 & 8 & 100 & \\
\hline \multicolumn{10}{|l|}{ Status Perkawinan } \\
\hline Lajang & 0 & 0 & 3 & 75,0 & 1 & 25,0 & 4 & 100 & \multirow{3}{*}{0,224} \\
\hline Menikah & 3 & 33,3 & 4 & 44,4 & 2 & 22,2 & 9 & 100 & \\
\hline Cerai/janda/duda & 6 & 21,6 & 4 & 21,1 & 9 & 47,7 & 19 & 100 & \\
\hline \multicolumn{10}{|l|}{ Status Bekerja } \\
\hline Masih bekerja & 2 & 40,0 & 2 & 40,0 & 1 & 20,0 & 5 & 100 & \multirow[t]{2}{*}{0,658} \\
\hline Tidak bekerja & 7 & 25,9 & 9 & 33,3 & 11 & 40,7 & 27 & 100 & \\
\hline \multicolumn{10}{|l|}{ Status Ekonomi } \\
\hline Menengah & 4 & 44,4 & 4 & 44,4 & 1 & 11,8 & 9 & 100 & \multirow[t]{2}{*}{0,144} \\
\hline Rendah & 5 & 21,7 & 7 & 30,4 & 11 & 47,8 & 23 & 100 & \\
\hline \multicolumn{10}{|c|}{ Lama Mengidap PGK } \\
\hline$\leq 1$ tahun & 8 & 30,8 & 10 & 38,5 & 8 & 30,8 & 26 & 100 & \multirow[t]{2}{*}{0,260} \\
\hline$>1$ tahun & 1 & 16,7 & 1 & 16,7 & 4 & 66,7 & 6 & 100 & \\
\hline
\end{tabular}

Tabel 2. Hubungan Karakteristik Pasien PGK dengan Tingkat Kecemasan saat Ditetapkan Mendapatkan Terapi Hemodialisis di Jakarta

\begin{tabular}{|c|c|c|c|c|c|c|c|c|c|}
\hline \multirow{3}{*}{ Karakteristik } & \multicolumn{6}{|c|}{ Tingkat Kecemasan } & & & \multirow{3}{*}{$P$ value } \\
\hline & \multicolumn{2}{|c|}{ Normal } & \multicolumn{2}{|c|}{$\begin{array}{l}\text { Ringan- } \\
\text { Sedang }\end{array}$} & \multicolumn{2}{|c|}{ Berat-Sangat Berat } & \multicolumn{2}{|c|}{ Total } & \\
\hline & $\mathbf{N}$ & $\%$ & $\mathbf{n}$ & $\%$ & $\mathbf{n}$ & $\%$ & $\bar{n}$ & $\%$ & \\
\hline \multicolumn{10}{|l|}{ Usia } \\
\hline Dewasa & 0 & 0 & 9 & 40,9 & 13 & 59,1 & 22 & 100 & \multirow[t]{2}{*}{$0,011^{*}$} \\
\hline Lansia & 2 & 20,0 & 0 & 0 & 8 & 80,0 & 10 & 100 & \\
\hline \multicolumn{10}{|l|}{ Jenis Kelamin } \\
\hline Laki-laki & 0 & 0 & 8 & 66,7 & 4 & 33,3 & 12 & 100 & \multirow{2}{*}{$0,001 *$} \\
\hline Perempuan & 2 & 10,0 & 1 & 5,0 & 17 & 85,0 & 20 & 100 & \\
\hline \multicolumn{10}{|l|}{ Tingkat Pendidikan } \\
\hline Tinggi & 1 & 14,3 & 3 & 42,9 & 3 & 42,9 & 7 & 100 & \multirow{3}{*}{0,427} \\
\hline Menengah & 0 & 0 & 4 & 23,5 & 13 & 76,5 & 17 & 100 & \\
\hline Rendah & 1 & 12,5 & 2 & 25,0 & 5 & 62,5 & 8 & 100 & \\
\hline \multicolumn{10}{|l|}{ Status Perkawinan } \\
\hline Lajang & 0 & 0 & 2 & 50 & 2 & 50 & 4 & 100 & \multirow{3}{*}{0,056} \\
\hline Menikah & 2 & 22,2 & 0 & 0 & 7 & 77,8 & 9 & 100 & \\
\hline Cerai/janda/duda & 0 & 0 & 7 & 36,8 & 12 & 63,2 & 19 & 100 & \\
\hline \multicolumn{10}{|l|}{ Status Bekerja } \\
\hline Masih bekerja & 0 & 0 & 4 & 80,0 & 1 & 20,0 & 5 & 100 & \multirow[t]{2}{*}{$0,019 *$} \\
\hline Tidak bekerja & 2 & 7,4 & 5 & 18,5 & 20 & 74,1 & 27 & 100 & \\
\hline \multicolumn{10}{|l|}{ Status Ekonomi } \\
\hline Menengah & 1 & 11,1 & 4 & 44,4 & 4 & 44,4 & 9 & 100 & \multirow[t]{2}{*}{0,284} \\
\hline Rendah & 1 & 4,3 & 5 & 21,7 & 17 & 73,9 & 23 & 100 & \\
\hline \multicolumn{10}{|c|}{ Lama Mengidap PGK } \\
\hline$\leq 1$ tahun & 2 & 7,7 & 9 & 34,6 & 15 & 57,7 & 26 & 100 & \multirow[t]{2}{*}{0,145} \\
\hline$>1$ tahun & 0 & 0 & 0 & 0 & 6 & 100 & 6 & 100 & \\
\hline
\end{tabular}




\section{Pembahasan}

Data dalam penelitian menyatakan tingkat stres berhubungan dengan usia (tabel 1). Hasil penelitian ini memperkuat penelitian 1 Kimmel (2001) yang menyatakan usia merupakan salah satu faktor yang berhubungan dengan respons psikologis pasien karena memengaruhi persepsi. Sebagian besar pasien lansia tidak mengalami stres peneliti menganalisa pasien dalam kategori usia dewasa memiliki stressor yang berbeda dengan pasien lansia. Apabila dihubungkan dengan usia harapan hidup, pasien dewasa memiliki sisa rentang kehidupan yang lebih lama daripada lansia. Dalam rentang kehidupan tersebut, pasien dewasa masih memikirkan karir, hubungan interpersonal, dan masa depan. Hal-hal yang seharusnya dapat mereka capai saat usia dewasa bisa terhambat karena efek negatif PGK. Ditambah lagi saat pasien ini mendengar ketetapan mendapatkan terapi $\mathrm{HD}$, semua bayangan tentang kehidupan yang tidak menyenangkan, seperti berhenti bekerja, hidup bergantung dengan mesin pencuci darah, dan karir yang menurun dapat muncul menjadi stressor. Sebaliknya, pasien lansia yang telah menghabiskan masa produktif cenderung pasrah terhadap keadaan. Tidak sedikit lansia yang berpikir bahwa PGK dan ketetapan mendapatkan terapi HD adalah sesuatu hal yang wajar dialami oleh orang yang telah berusia lanjut. Analisis ini diperkuat oleh penelitian Marosti dan Dantas (2006) yang mengatakan pasien yang berusia lebih tua memiliki tingkat toleransi terhadap stres yang lebih baik (Carstensen et al., 2000 dalam Oktug, 2013).

Hasil penelitian menunjukkan laki-laki yang mengalami stres berat hingga sangat berat lebih banyak dibandingkan perempuan. Penelitian ini berbeda dengan penelitian yang dilakukan Marosti dan Dantas (2006) yang menemukan hal sebaliknya. Fenomena tersebut dapat disebabkan karena adanya perbedaan kultur pada tempat penelitian yang dilakukan. Di Indonesia laki-laki mengambil peranan penting dalam kehidupan sehari-hari, yaitu kewajiban memenuhi kebutuhan ekonomi, memberi rasa aman, dan membuat keputusan. Ketetapan mendapatkan terapi HD dapat menjadi sebuah stressor bagi laki-laki karena laki-laki berpikir bahwa ketika ia harus menjalani terapi HD, ia tidak dapat menjalankan semua kewajibannya dengan optimal. Selain itu, rasa rendah diri dapat muncul pada laki-laki apabila peran mereka kemudian diambil alih oleh perempuan.

Penelitian ini menunjukkan sebagian besar pasien PGK yang berpendidikan tinggi tidak mengalami stres, sedangkan sebagian besar pasien berpendidikan rendah mengalami stres berat hingga sangat berat. Hasil uji statistik menunjukkan terdapat hubungan antara tingkat pendidikan dengan tingkat stres. Tingkat pendidikan menjadi faktor yang dapat mempengaruhi tingkat pengetahuan. Semakin tinggi tingkat pendidikan pasien akan semakin mudah terpapar dengan informasi terkait HD, sehingga saat ditetapkan mendapatkan terapi HD, pasien telah siap dan tahu apa keputusan yang akan diambil (Kimmel, 2001; Notoatmodjo, 2003; Pertiwi, 2013).

Penelitian ini menunjukkan tidak terdapat hubungan antara status perkawinan dengan tingkat stres. Hasil uji ini memperkuat penelitian yang dilakukan oleh Wade, Hart, Wade, Bajaj, dan Price (2013) yang mengatakan tidak terdapat hubungan antara status perkawinan dengan perasaan tidak nyaman pada pasien dengan penyakit kronis. Pasien yang masih lajang terlihat lebih banyak berada di tingkat stres ringan hingga sedang. Hal ini dapat disebabkan karena saat berstatus lajang, pasien tidak memiliki tanggungan yang dapat menjadi beban pikiran. Di lain sisi, pasien lajang dapat memiliki perasaan ketakutan yang lebih besar mengingat mereka belum menikah. Perasaan khawatir bahwa mereka tidak akan menikah selamanya dapat muncul seiring dengan penurunan status kesehatan. Sementara itu, pasien yang telah bercerai, janda, atau duda juga dapat memiliki stressor yang lebih pelik. Tingginya persentase pasien kelompok ini yang mengalami stres berat hingga sangat berat dapat disebabkan karena adanya kekhawatiran 
bahwa tidak akan ada orang yang mau mengurus mereka ketika mereka sakit. Lain halnya dengan pasien yang telah menikah Koenig, McCullough, dan Larson (2001) dalam penelitiannya membuktikan terdapat hubungan antara penurunan mortalitas dengan ketersediaan dukungan sosial yang diyakini dapat meningkatkan kesehatan fisik dan mental setiap orang. Pasien yang telah menikah dan mempunyai pasangan intim akan menerima dukungan yang terus menerus. Hal ini menyebabkan pasien memiliki pertahanan dan kesiapan ketika mendengar ketetapan mendapatkan terapi HD.

Hasil penelitian menunjukkan pasien lansia yang mengalami kecemasan berat hingga sangat berat lebih mendominasi. Pasien yang lebih tua idealnya memliki kepribadian yang lebih matang (Lutfa \& Maliya, 2008). Namun perlu dipahami bahwa usia bukan satu-satunya faktor yang mempengaruhi kematangan kepribadian. Terdapat variabel lainnya yang memiliki pengaruh, seperti pengalaman, pemahaman, dan kondisi spiritual. Beberapa lansia mungkin tidak mampu beradaptasi dengan baik terhadap proses menua yang dihadapinya. Penelitian menunjukkan terdapat hubungan antara jenis kelamin dengan tingkat kecemasan. Penelitian ini memperkuat penelitian Caninsti (2007). Perempuan dikatakan memiliki reaksi emosional yang lebih hebat yang mengarah pada perbedaan temperamen perempuan dalam menghadapi stressor dan berdampak kepada tingkat kecemasannya. HD dan PGK memberikan efek terhadap tubuh baik secara fisik maupun psikis. Dari segi fisik, pasien PGK terlihat lemas, pucat, dan tidak jarang muka terlihat menghitam akibat penumpukan sisa metabolisme dalam tubuh. Hal ini dapat mempengaruhi citra tubuh, terutama bagi perempuan yang cenderung memperhatikan penampilan. Dari segi biologis, perempuan yang menjalani HD sulit hamil dan memiliki keturunan. Perasaan mual, muntah, dan tidak bertenaga yang dirasakan pasien dapat menyebabkan terganggunya hubungan seksualitas. Kekhawatiran kehilangan peran dan kecantikan sebagai perempuan dapat memicu munculnya kecemasan.

Angka kecemasan berat hingga sangat berat yang paling besar terdapat pada pasien yang telah menikah . Hasil uji statistik menunjukkan terdapat hubungan antara status perkawinan dengan tingkat kecemasan. Penelitian ini memperkuat penelitian Scott, et al., (2010) yang menemukan adanya hubungan antara status perkawinan dengan respons pertama kecemasan. Peneliti meyakini setiap pasien mempunyai stressor tersendiri terkait status perkawinan. Pasien PGK yang masih lajang dapat memiliki stressor yang berhubungan dengan keinginan untuk menikah, khawatir tidak dapat merasakan peran suami/istri dan ayah/ibu. Pasien PGK yang telah bercerai, dapat memiliki kecemasan yang disebabkan karena minimnya tempat berbagi cerita atau kehilangan orang-orang yang pernah dekat dahulunya. Scott, et al., (2010) dalam penelitiannya mengatakan bahwa perkawinan dapat mengurangi risiko terjadinya kecemasan pada pasien. Perkawinan menghubungkan seseorang dengan individu lainnya, lalu dengan kelompok sosial, dan kemudian institusi sosial yang membuat individu tersebut memiliki tambahan dukungan sosial (Stolzenberg, Loy, \& Waite, 1995 dalam Wade, Hart, Wade, Bajaj, dan Price, 2013). Akan tetapi dalam penelitian ini ditemukan sebaliknya, pasien menikah justru paling banyak mengalami stres berat hingga sangat berat. Menurut peneliti hal ini berhubungan dengan konflik dalam perkawinan yang rentan terjadi. Konflik dapat mempengaruhi persepsi dan mengganggu kemampuan pasien dalam bertahan terhadap stressor.

Sebagian besar pasien yang bekerja berada dalam tingkat kecemasan ringan hingga sedang, sementara mayoritas pasien yang sudah tidak bekerja berada dalam tingkat kecemasan berat hingga sangat berat. Hasil uji statistik menunjukkan terdapat hubungan antara status bekerja dengan tingkat kecemasan. Penelitian ini memperkuat penelitian Chontessa, Singara, dan Idrus (2012) yang menyimpulkan persen- 
tase kecemasan berat dan sedang lebih banyak terjadi pada pasien yang tidak bekerja. Pasien yang masih bekerja memiliki kesempatan mendapat dukungan sosial yang lebih banyak daripada pasien yang tidak bekerja. Selain itu, menurut peneliti sampai saat ini status sosial masih dinilai dari status pekerjaan seseorang. Pasien PGK yang sudah tidak bekerja mungkin saja merasakan bahwa masyarakat memiliki stigma yang buruk terhadap dirinya. Pasien yang tidak bekerja dianggap sebagai orang yang tidak berguna dalam lingkungan sosial. Hal ini dapat memperparah perasaan ketidakberdayaan yang dimiliki pasien. Di lain pihak, pasien PGK yang masih bekerja justru merasa bahwa ia masih dapat memberi manfaat walaupun dalam keadaan sakit. Hal ini dapat meningkatkan harga diri pasien tersebut. Stigma dan perasaan berharga tersebut yang membedakan tingkat kecemasan yang dirasakan antara pasien PGK yang masih bekerja dengan yang sudah tidak bekerja.

\section{Kesimpulan}

Hasil penelitian ini membuktikan terdapat hubungan antara tingkat stres pasien PGK saat ditetapkan mendapatkan terapi hemodialisis dengan karakteristik usia dan tingkat pendidikan. Sementara tingkat kecemasan saat ditetapkan mendapatkan terapi hemodialisis berhubungan dengan usia, jenis kelamin, status perkawinan, dan status bekerja pasien PGK. Hasil penelitian memberikan informasi kepada tenaga kesehatan agar dapat menemukan intervensi yang tepat untuk menurunkan tingkat stres dan kecemasan. Penelitian secara berkelanjutan terhadap perubahan status stres dan kecemasan yang dirasakan pasien PGK mulai dari awal diberikan ketetapan hingga akhirnya pasien menjalani terapi HD perlu dilakukan. Untuk mengetahui hal-hal apa saja yang dapat mengurangi ataupun menambah tingkat stres dan kecemasan yang dirasakan oleh pasien (IC, PN, HR).

\section{Referensi}

Andrade, C.P., \& Sesso, R.C. (2012). Depression in chronic kidney disease and hemodialysis patients. Scientific Research, 3 (11), 974-978. doi: 10.4236/psych.2012.311146

Baradero, M., Dayrit, M.W., \& Siswadi, Y. (2005). Klien gangguan ginjal: Seri asuhan keperawatan. Jakarta: EGC.

Caninsti, R. (2007). Gambaran kecemasan dan depresi pada penderita gagal ginjal kronis yang menjalani terapi hemodialisa. (Tesis, tidak dipublikasikan). Depok: Pascasarjana Fakultas Psikologi UI.

Chontessa, T.J., Singara, T., \& Idrus, F. (2012). Hubungan beratnya gejala ansietas dengan masa klimakterium wanita di Rumah Sakit Pendidikan Makassar. Makassar: Bagian Ilmu Kedokteran Jiwa Universitas Hasanuddin.

DeLaune, S.C., \& Ladner, P.K. (2011). Fundamentals of nursing: Standars and practice (4th Ed.). USA: Delmar, Cengage Learning.

Farida, A. (2010). Pengalaman klien hemodialisis terhadap kualitas hidup dalam konteks asuhan keperawatan di RSUP Fatmawati Jakarta. (Tesis, tidak dipublikasikan). Pascasarjana Fakultas Ilmu Keperawatan Kekhususan Keperawatan Medikal Bedah Universitas Indonesia, Depok, Jawa Barat, Indonesia

Kimmel, P.L. (2001). Psychosocial factors in dialysis patients. Kidney International, 59, 1599-1613. doi: http://dx.doi.org/10.1046/j. 1523-1755.2001.0590041599.x

Koenig, H.G., McCullough, M.E. \& Larson, D.B. (2001). Handbook of religion and health. New York: Oxford University Press.

Lutfa, U., \& Maliya, A. (2008). Faktor-faktor yang mempengaruhi kecemasan pasien dalam tindakan kemoterapi di Rumah Sakit Dr. Moewardi Surakarta. Berita Ilmu Keperawatan, 1 (4), 187-192. 
Marosti, C.A., \& Dantas, R.A.S. (2006). Relation between stressors and sociodemographic and clinical characteristics of patients hospitalized at a coronary unit. Latino-am Enfermagem Setembro-Outubro, 14 (5), 713-719. Diperoleh dari http://www.scielo.br/pdf/rlae/v14n5/v14n 5a12.pdf

Notoatmodjo, S. (2010). Metodologi penelitian kesehatan. Jakarta: Rineka Cipta.

Oktug, Z. (2013). The realtionship between emotion management and the acting mechanisms used in performing emotional labor: Do gender and age make a difference? The Journal of American Academy of Business, Cambridge, 19, 118-125.

Pertiwi, R.I. (2013). Gambaran pengetahuan dan perilaku mencari pelayanan kesehatan pada pasien kanker payudara di Rumah Sakit Kanker Dharmais.(Tesis, magister tidak dipublikasikan). Fakultas Ilmu Keperawatan Program Studi Sarjana Universitas Indonesia, Depok, Jawa Barat, Indonesia

Scott, K. M., Wells, E., Angermeye, M., Brugha, T., Bromet, E., Demyttenaere, K., Girolamo, K... Kessler, R. (2010). Gender and the relationship between marital status and first onset of mood, anxiety, and substance use disorders. Psychol Med, 9, 1495-505. doi: 10.1017/S0033291709991942

Wade, J.B., Hart, R.P., Wade, J.H., Bajaj, J.S., \& Price, D.D. (2013). The relationship between marital status and psychological resilience in chronic pain. Pain Research and Treatment, 2013, Article ID 928473. doi: http://dx. doi.org/10.1155/2013/928473. 
